\title{
PREDIKSI JANGKA PANJANG TRANSMISI KEBIJAKAN MONETER MELALUI JALUR KURS NEGARA EMERGING MARKET
}

\author{
Ade Novalina ${ }^{1}$ \\ Dosen Fakultas Ekonomi dan Bisnis Universitas Pembangunan Panca Budi \\ email : adenovalina@dosen.pancabudi.ac.id \\ Rusiadi $^{2}$ \\ Dosen Fakultas Ekonomi dan Bisnis Universitas Pembangunan Panca Budi \\ email : rusiadi@dosen.pancabudi.ac.id
}

\begin{abstract}
ABSTRAK
Penelitian ini bertujuan menganalisis pola efektifitas transmisi kebijakan moneter negara emerging market dengan menganalisis model Mundell-Fleming. Menganalisis seberapa besar pengaruh pdb, kurs, investasi terhadap kestabilan inflasi negara emergingmarket. Data dianalisis berdasarkan time series tahun 2000-2016. Negara emerging market yang dipilih adalah India, Brazil, China, rusia, Indonesia. Analisis data menggunakan analisis jangka panjang Vector Autoregression, Impulse Response function dan variance decomposition. Hasil persamaan untuk ekspor negera emerging market diketahui ekspor tahun sebelumnya sangat mempengaruhi ekspor tahun sekarang, kemudian inflasi juga mempengaruhi signifikan. Perkembangan ekonomi yang diwakili oleh inflasi dipengaruhi oleh inflasi tahun sebelumnya dan ekspor. Investasi sangat dipengaruhi oleh inflasi dan ekspor. Untuk produk domestik bruto dipengaruhi oleh inflasi dan ekspor dan untuk kurs dipengaruhi oleh inflasi dan ekspor. Hasil tersebut menunjukkan kebijakan moneter negara-negara emerging market sangat dipengaruhi oleh inflasi dan ekspor.
\end{abstract}

Kata Kunci : emerging market, transmisi kebijakan moneter, stabilitas ekonomi

\section{PENDAHULUAN}

Stabilitas ekonomi sebagai suatu kondisi yang tercermin dari membaiknya fundamental makro ekonomi. Untuk mendukung stabilitas ekonomi makro yang lebih optimal serta menciptakan kerangka kebijakan moneter yang kuat dan antisipatif maka maka diperlukan adanya kebijakan moneter yang tepat dalam mencapai sasaran stabilitas dalam jangka panjang. Mekanisme transmisi kebijakan moneter merupakan suatu proses dimana suatu kebijakan yang dibuat dapat mempengaruhi pertumbuhan ekonomi dan inflasi dalam suatu negara, saluran transmisi kebijakan moneter dilakukan melalui enam saluran yaitu suku bunga, kredit, harga aset, neraca perusahaan, nilai tukar dan ekspektasi, kebijakan ini seluruhnya dijalankan oleh bank sentral yang merupakan mitra utama pemerintah dalam menggerakkan dan menjalankan berbagai kegiatan ekonomi melalui kebijakan-kebijakan yang ditetapkannya.

Fenomena masalah dalam penelitian ini yaitu dengan melihat respon variabelvariabel makro ekonomi terhadap efektifitas transmisi kebijakan moneter negara emergingmarket dalam periode penelitian tahun 2000 sampai dengan tahun 2016 sebagai berikut : 


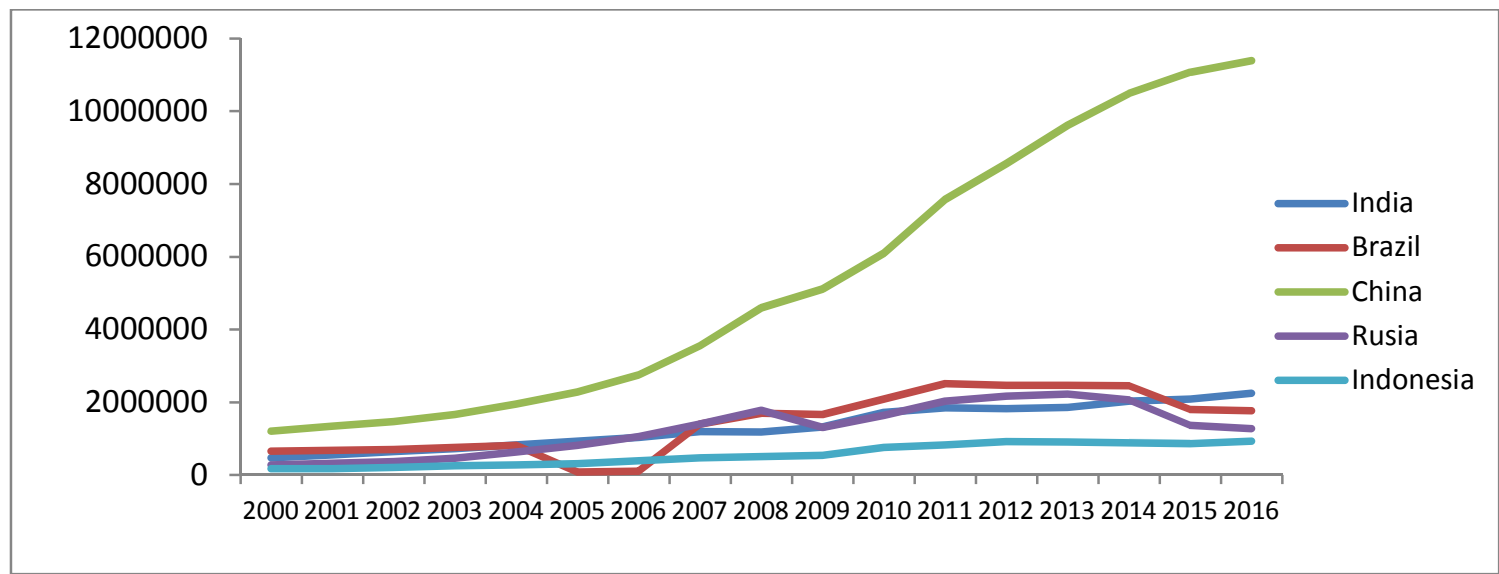

Gambar 1

Perkembangan PDB negara emerging market Tahun 2000-2016

Berdasarkan grafik di atas diketahui bahwa adanya pertumbuhan PDB negara emerging market tahun 2009 menurun dari tahun sebelumnya, India menurun 6,06\%, Brazil sebesar $7,19 \%$, China menurun $-0,6 \%$, Rusia menurun $2 \%$, dan Indonesia menurun $8,27 \%$ yang diakibatkan guncangan dan ketidakjelasan finansial gobal.

Krisis ekonomi Amerika tersebut yang semakin lama semakin merambat menjadi krisis ekonomi global karena sebenarnya perekonomian di dunia ini saling terhubung satu sama lainnya, peristiwa yang terjadi di suatu tempat akan berpengaruh di tempat lainnya. Oleh karena itu Indonesia juga turut merasakan krisis ekonomi global ini. Indonesia merupakan negara yang masih sangat bergantung dengan aliran dana dari investor asing, dengan adanya krisis global ini secara otomatis para investor asing tersebut menarik dananya dari Indonesia.

Nilai ekspor Indonesia juga berperan dalam sebagai penyelamat dalam krisis global tahun 2008 lalu. Kecilnya proporsi ekspor terhadap PDB (Produk Domestik Bruto) cukup menjadi penyelamat dalam menghadapi krisis finansial di akhir tahun 2008 lalu. Di regional Asia sendiri, Indonesia merupakan negara yang mengalami dampak negatif paling ringan dari krisis tersebut dibandingkan negara lainnya. Beberapa pihak mengatakan bahwa 'selamat'nya Indonesia dari gempuran krisis finansial yang berasal dari Amerika itu adalah berkat minimnya proporsi ekspor terhadap PDB. Negara-negara yang memiliki rasio ekspor dengan PDB yang tinggi mengalami pertumbuhan ekonomi yang negatif.

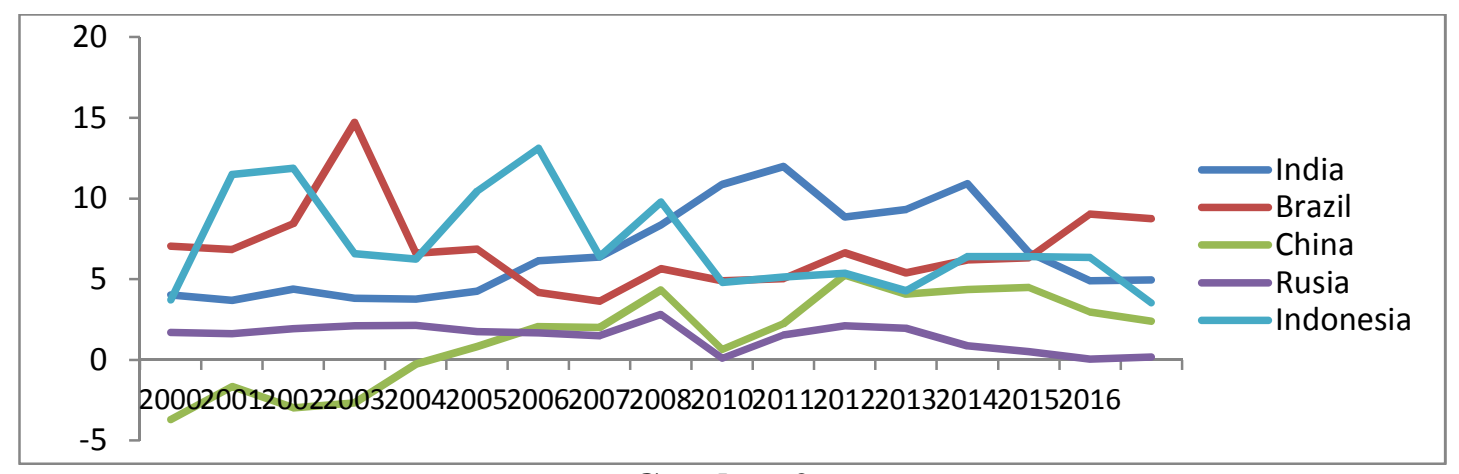

Gambar 2

laju Inflasi negara emerging market Tahun 2001- 2014 
Berdasarkan gambar di atas diketahui terjadi kenaikan inflasi tahun 2008 , India naik 8,35\%, Brazil naik 5,66\%, China naik 6,46\%, Russia naik14,10\%, Indonesia 9,77\% . hal ini disebabkan dampak kenaikan harga minyak dunia dan kenaikan BBM akibat efek krisis ekonomi global yang meningkatkan harga-harga barang. Berdasarkan APBN 2008 yang telah dirubah, asumsi harga minyak menjadi US\$ 95 per barel. Dengan asumsi tersebut maka subsidi Bahan Bakar Minyak (BBM) diperhitungkan sebesar Rp. 126 trilyun.

Namun harga minyak selama tahun 2008 ini terus merangkak naik dan pada bulan Mei telah melewati harga diatas US\$ 130. Tanpa kenaikan harga maka subsidi BBM akan menggelembung sampai Rp.190 trilyun. Akibatnya akan terjadi defisit anggaran yang sangat besar yang dikhawatirkan akan mengacaukan realisasi APBN 2008. Padahal menurut UU No 16/2008 tentang APBN(P) 2008 yang disetujui DPR, ditetapkan batas maksimal anggaran subsidi BBM hanya sebesar Rp 135,1 triliun.

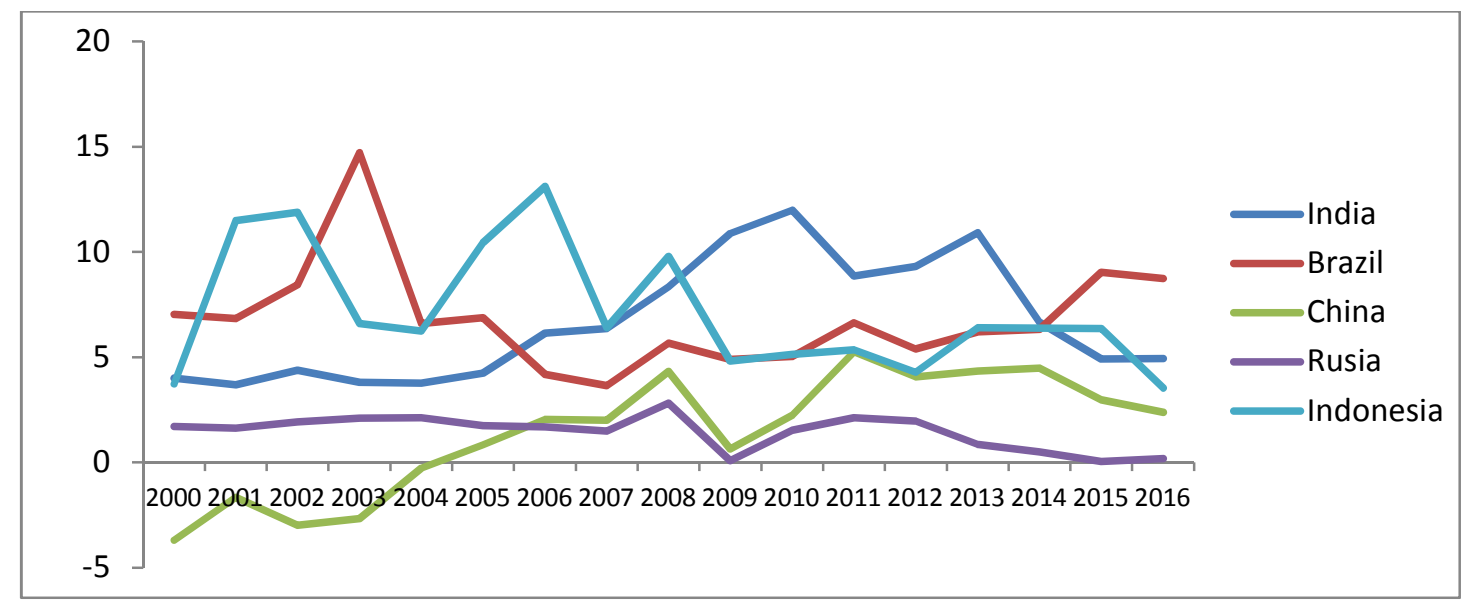

Gambar 3

Perkembangan kurs rupiah - dolar (\%) Tahun 2000-2016

Berdasarkan grafik di atas diketahui terjadi penurunan nilai tukar tahun 2010, India menurun $-14,25 \%$, Brazil menurun $-14,97 \%$, Russia menurun $-8,68 \%$, Indonesia menurun $-4,35 \%$, ( kecuali China naik $-0,58 \%$ ). Tugas pokok BI saat ini menjadi lebih fokus karena memiliki sasaran tunggal. Namun, dalam pelaksanaannya tugas tersebut cukup berat mengingat kestabilan nilai rupiah tidak sepenuhnya dapat dikendalikan oleh BI. BI hanya memiliki kemampuan untuk mempengaruhi tekanan inflasi dari sisi permintaan, sedang tekanan inflasi yang berasal dari sisi penawaran sepenuhnya berada diluar pengendalian BI. Demikian pula, dengan ditetapkannya sistem nilai tukar mengambang bebas maka nilai tukar rupiah akan sepenuhnya ditetapkan oleh kekuatan pasar. Tujuan tunggal kebijakan moneter BI untuk menjaga stabilitas nilai rupiah terangkum dalam kerangka kerja penargetan inflasi. Dalam penerapan penargetan inflasi, kebijakan moneter dijalankan dengan menggunakan suku bunga sebagai sasaran operasionalnya. Sementara itu, pemilihan suku bunga yang dijadikan sebagai sasaran operasional kebijakan moneter masih meninggalkan perdebatan. Perdebatan tersebut berkisar pada apakah suku bunga SBI atau suku bunga PUAB yang tepat dijadikan sebagai sasaran operasional kebijakan moneter. Penelitian ini menggunakan suku bunga SBI sebagai sasaran operasional untuk mengetahui kemampuan suku bunga SBI sebagai 
sasaran operasional dalam mentransmisikan kebijakan moneter pada beberapa variabel makroekonomi Indonesia.

Dalam penerapan penargetan inflasi, kerangka kebijakan moneter dijalankan dengan pendekatan berdasarkan harga besaran moneter. Kebijakan moneter dengan pendekatan harga besaran moneter dapat berpengaruh efektif terhadap pengendalian tingkat inflasi melalui saluran suku bunga dan nilai tukar (Kharie, 2006). Pada penelitian ini sasaran operasional yang digunakan adalah suku bunga SBI satu bulan. Sementara itu, variabel-variabel informasi yang digunakan, antara lain suku bunga deposito satu bulan, jumlah uang beredar dalam arti sempit (M1), PDB, dan nilai tukar yang juga mencerminkan stabilitas nilai rupiah terhadap mata uang negara lain.

\section{LANDASAN TEORITIS}

Tingkat bunga merupakan kunci mekanisme transmisi moneter dalam model IS, model LM, model AD dan model AS. Peningkatan stok uang akan menurunkan tingkat bunga riil dan biaya modal serta meningkatkan investasi bisnis. Peningkatan investasi akan meningkatkan permintaan agregat. Penurunan tingkat bunga riil juga akan meningkatkan pengeluaran untuk pembelian rumah dan barang tahan lama. Oleh sebab itu penurunan tingkat bunga akibat ekspansi moneter akan meningkatkan belanja atau konsumsi dan permintaan agregat. Pada tingkat bunga nominal yang sangat rendah, ekspansi moneter akan meningkatkan ekspektasi tingkat harga dan inflasi, akibatnya tingkat bunga riil turun. Penurunan tingkat bunga riil akan menurunkan biaya modal dan biaya memegang uang, kemudian menstimulasi pengeluaran bisnis dan konsumen. Peningkatan pengeluaran bisnis dan konsumen pada akhirnya akan mingkatkan permintaan agregat. Mekanisme transmisi alur tingkat bunga dirumuskan dalam dua bentuk, yaitu :

$$
\begin{aligned}
& \mathbf{m} \uparrow \rightarrow \mathbf{r} \downarrow \rightarrow \pi \uparrow \rightarrow \mathbf{y} \uparrow \\
& \mathbf{m} \uparrow \rightarrow \mathbf{p} \uparrow \rightarrow \mathbf{r} \downarrow \rightarrow \pi \uparrow \rightarrow \mathbf{y} \uparrow
\end{aligned}
$$

dimana:

$\mathrm{m}=$ stok uang nominal,

$\mathrm{r}=$ tingkat bunga riil,

$\mathrm{p}=$ ekspektasi tingkat harga,

$\pi=$ investasi riil, dan

$\mathrm{y}=$ output riil agregat.

Model Cagan adaptive expectation dimulai dari model permintaan uang dalam bentuk fungsi eksponensial, yaitu:

$$
\frac{M_{t}}{P_{t}}=e^{\alpha_{0}+\alpha_{2} R_{t}} y_{t}^{\alpha_{1}} \text { atau } \ln \frac{M_{t}}{P_{t}}=\alpha_{0}+\alpha_{1} \ln \left(y_{t}\right)+\alpha_{2} R_{t}+\mu_{t}
$$

Diketahui bahwa nilai $\mathrm{R}_{\mathrm{t}}=\mathrm{r}_{\mathrm{t}}+\pi_{\mathrm{t}}$ dimana $\mathrm{r}_{\mathrm{t}}$ adalah tingkat bunga riil, dan substitusi tingkat bunga nominal $[R]$ dengan $r+\pi$ akan merubah model permintaan uang menjadi: 


$$
\begin{aligned}
& \ln \frac{M_{t}}{P_{t}}=\alpha_{0}+\alpha_{1} \ln \left(y_{t}\right)+\alpha_{2} r_{t}+\alpha_{2} \pi_{t}+\mu_{t} \\
& \ln \frac{M_{t}}{P_{t}}=\lambda+\alpha \pi_{t}+\mu_{t}
\end{aligned}
$$

dimana $\pi_{\mathrm{t}}=$ ekspektasi inflasi, $\lambda=\alpha_{0}+\alpha_{1} \ln \left(y_{t}\right)+\alpha_{2} r_{t}$ dan $\alpha=\alpha_{2}$. Misalkan $\ln \left(\mathrm{M}_{\mathrm{t}}\right)=\mathrm{m}_{\mathrm{t}}$ dan $\ln \left(\mathrm{P}_{\mathrm{t}}\right)=\mathrm{p}_{\mathrm{t}}$ sehingga persamaan (1.2) berubah menjadi:

$m_{t}-p_{t}=\lambda+\alpha \pi_{t}+\mu_{t}$

Model Cagan menjelaskan bahwa ekspektasi inflasi merupakan ekspektasi perubahan tingkat harga pada masa datang, yaitu: $\Delta p_{t+1}=p_{t+1}-p_{t}$. Model ekspektasi inflasi Cagan merupakan dasar kerja Milton Friedman, dan kemudian Friedman menyebutnya sebagai model ekspektasi adaptif atau adaptive expectation, yaitu:

$$
\pi_{t}-\pi_{t-1}=\rho\left(\Delta p_{t}-\pi_{t-1}\right) \quad 0 \leq \rho \leq 1
$$

$\Delta p_{t}$ sebagai ukuran tingkat inflasi aktual dapat lebih kecil atau lebih besar dari nilai ekspektasi inflasi periode sebelumnya. Jika $\Delta p_{t} \prec \pi_{t-1}$ maka nilai $\pi_{t} \prec \pi_{t-1}$, sebaliknya jika $\Delta p_{t} \succ \pi_{t-1}$ maka nilai $\pi_{t} \succ \pi_{t-1}$. Persamaan (1.4) dapat dirubah menjadi:

$$
\begin{aligned}
& \pi_{t}=\rho \Delta p_{t}+(1-\rho) \pi_{t-1} \\
& \pi_{t-1}=\rho \Delta p_{t-1}+(1-\rho) \pi_{t-2} \\
& \quad \pi_{t-2}=\rho \Delta p_{t-2}+(1-\rho) \pi_{t-3}
\end{aligned}
$$

Proses iteratif adalah susbtitusi persamaan kedua ke persamaan pertama dan persamaan ketiga ke persamaan kedua dari (1.15), sehingga tingkat inflasi aktual periode [t] adalah

$$
\begin{aligned}
& \pi_{t}=\rho \Delta p_{t}+(1-\rho)\left\{\rho \Delta p_{t-1}+(1-\rho)\left[\rho \Delta p_{t-2}+\rho(1-\rho) \pi_{t-3}\right]\right\} \\
& \pi_{t}=\rho \Delta p_{t}+(1-\rho) \rho \Delta p_{t-1}+(1-\rho)^{2}\left[\rho \Delta p_{t-2}+\rho(1-\rho) \pi_{t-3}\right] \\
& \pi_{t}=\rho \Delta p_{t}+\rho(1-\rho) \Delta p_{t-1}+\rho(1-\rho)^{2} \Delta p_{t-2}+\rho(1-\rho)^{3} \pi_{t-3}+\ldots
\end{aligned}
$$

Jika persamaan (1.6) diteruskan sampai periode takberhingga maka nilai inflasi periode $[\mathrm{t}$ ] merupakan rata-rata tertimbang dari inflasi sekarang dan inflasi periode sebelumnya, yaitu:

$$
\pi_{t}=\rho \Delta p_{t}+(1-\rho) \pi_{t-1}
$$

Substitusi persamaan (1.7) ke (1.3) dan hasil substitusi mundur satu periode atau [t - 1] menghasilkan model permintaan uang periode [t] dan [t - 1], yaitu:

$$
\begin{aligned}
& m_{t}-p_{t}=\lambda+\alpha\left[\rho \Delta p_{t}+(1-\rho) \pi_{t-1}\right]+\mu_{t} \\
& m_{t-1}-p_{t-1}=\lambda+\alpha \pi_{t-1}+\mu_{t-1} \\
& \pi_{t-1}=\frac{m_{t-1}-p_{t-1}-\lambda-\mu_{t-1}}{\alpha}
\end{aligned}
$$

Substitusi persamaan (1.8B) ke (1.8A) akan menghasilkan model permintaan uang sebagai berikut:

$$
\begin{aligned}
& m_{t}-p_{t}=\lambda+\alpha\left(\rho \Delta p_{t}+(1-\rho) \frac{m_{t-1}-p_{t-1}-\lambda-\mu_{t-1}}{\alpha}\right)+\mu_{t} \\
& m_{t}-p_{t}=\lambda+\alpha \rho \Delta p_{t}+(1-\rho) m_{t-1}-(1-\rho) p_{t-1}
\end{aligned}
$$




$$
\begin{aligned}
& \quad(1-\rho) \lambda-(1-\rho) \mu_{t-1}+\mu_{t} \\
& m_{t}-p_{t}=\rho \lambda+\alpha \rho \Delta p_{t}+(1-\rho)\left[m_{t-1}-p_{t-1}\right]+\varepsilon_{t} \\
& \text { dimana } \varepsilon_{t}=-(1-\rho) \mu_{t-1}+\mu_{t} . \text { Model Cagan pada persamaan (1.9) dapat }
\end{aligned}
$$

diestimasi dengan metode OLS. Jika hasil penaksiran menghasilkan $0 \leq \rho \leq 1$ dan nilai $\alpha<0$ maka hal ini sesuai dengan teori. Fluktuasi nilai $\left[\mathrm{m}_{\mathrm{t}}-\mathrm{p}_{\mathrm{t}}\right]$ ditunjukkan oleh koefisien determinasi regressi OLS persamaan (1.9). Apabila nilai koefisien determinasi $\left[R^{2}\right]$ tinggi maka ada indikasi inflasi tinggi atau fluktuasi permintaan uang riil tinggi, sebaliknya jika koefisien determinasi $\left[R^{2}\right]$ rendah maka ada indikasi inflasi rendah atau fluktuasi permintaan uang riil rendah.

Begitu juga sebaliknya masing-masing variabel dari kebijakan moneter sangat merespon dan sangat berpengaruh terhadap variabel-variabel dari stabilitas ekonomi makro konsep penelitian dapat dilihat pada gambar berikut :

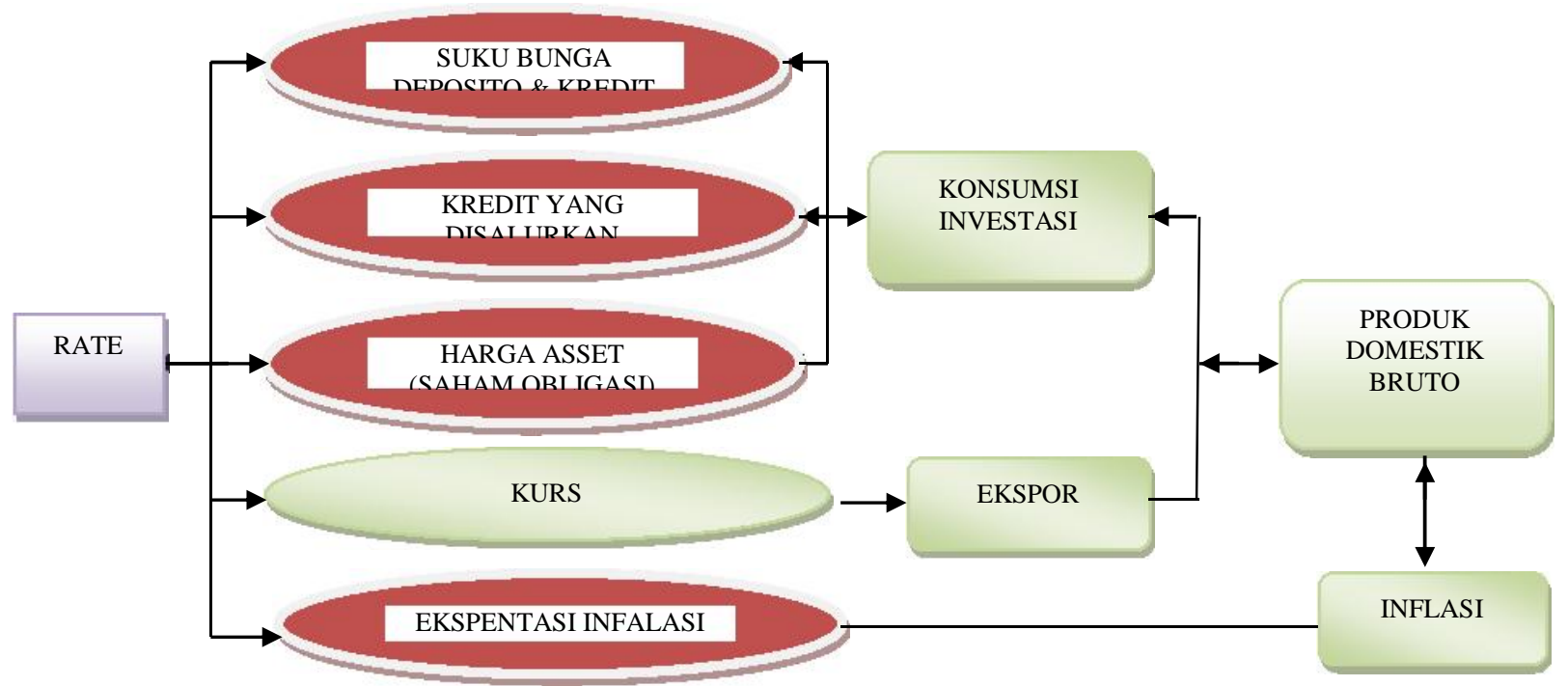

\section{Gambar 4 \\ Kerangka Konseptual \\ Efektifitas transmisi kebijakan moneter negara emerging market}

\section{METODOLOGI PENELITIAN}

Berdasarkan pendapat di atas penulis menggunakan VAR dengan alasan kemudahan dalam menjawab dan membuktikan secara empiris dan lebih kompleks hubungan timbal balik dalam jangka panjang variabel ekonomi dijadikan sebagai variabel endogen.

Model Analisis VAR dengan rumus :

$$
\begin{aligned}
T A X_{t}= & \beta_{10} G O V_{t-p}+\beta_{11} S B K_{t-p}+\beta_{12} J U B_{t-p}+\beta_{13} P D B_{t-p}+\beta_{14} I N V_{t-p}+\beta_{15} K U R S_{t-p} \\
& +\beta_{16} I N F_{t-p}+\beta_{17} T A X_{t-p}+e_{t 1} \\
J U B_{t}= & \beta_{40} I D B_{t-p}+\beta_{41} I N V_{t-p}+\beta_{42} K U R S_{t-p}+\beta_{43} I N F_{t-p}+\beta_{44} T A X_{t-p}+\beta_{45} G O V_{t-p} \\
& +\beta_{46} S B K_{t-p}+\beta_{47} J U B_{t-p}+e_{t 4} \\
P D B_{t}= & \beta_{50} I N V_{t-p}+\beta_{51} K U R S_{t-p}+\beta_{52} I N F_{t-p}+\beta_{53} T A X_{t-p}+\beta_{54} G O V_{t-p}+\beta_{55} S B K_{t-p} \\
& +\beta_{56} J U B_{t-p}+\beta_{57} P D B_{t-p}+e_{t 5}
\end{aligned}
$$




$$
\begin{aligned}
I N V_{t}= & \beta_{60} K U R S_{t-p}+\beta_{61} I N F_{t-p}+\beta_{62} T_{A X}+\beta_{t-p} G O V_{t-p}+\beta_{64} S B K_{t-p}+\beta_{65} J U B_{t-p} \\
& +\beta_{66} P_{t-p}+\beta_{67} I N V_{t-p}+e_{t 6} \\
K U R S_{t} & =\beta_{70} I N F_{t-p}+\beta_{71} T A X_{t-p}+\beta_{72} G O V_{t-p}+\beta_{73} S B K_{t-p}+\beta_{74} J U B_{t-p}+\beta_{75} P D B_{t-p} \\
& +\beta_{77} I N V_{t-p}+\beta_{77} K U R S_{t-p}+e_{t 7} \\
I N F_{t}= & \beta_{80} T A X_{t-p}+\beta_{81} G O V_{t-p}+\beta_{82} S B K_{t-p}+\beta_{83} J U B_{t-p}+\beta_{84} P D B_{t-p}+\beta_{85} I N V_{t-p} \\
& +\beta_{86} K U R S_{t-p}+\beta_{87} N F_{t-p}+e_{t 8}
\end{aligned}
$$

Dimana :

$$
\begin{array}{ll}
\text { INF } & =\text { inflasi }(\%) \\
\text { EX } & =\text { Ekspor }(\%) \\
\text { JUB } & =\text { Jumlah Uang Beredar (Milyar Rp) } \\
\text { PDB } & =\text { Product Domestik Bruto (Milyar Rp) } \\
\text { INV } & =\text { Investasi Asing Langsung (Juta US\$) } \\
\text { KURS } & =\text { Kurs dolar per rupiah (Rp/US\$) } \\
\text { et } & =\text { Guncangan acak (random disturbance) } \\
\text { p } & =\text { panjang lag }
\end{array}
$$

\begin{tabular}{|c|c|c|}
\hline Periode & Terbesar 1 & Terbesar 2 \\
\hline $\begin{array}{c}\text { Jangka Pendek } \\
\text { (Periode 1) }\end{array}$ & $\begin{array}{c}\text { INF } \\
90.16161 \%\end{array}$ & $\begin{array}{c}\mathrm{EX} \\
9.838387 \%\end{array}$ \\
\hline $\begin{array}{l}\text { Jangka Menegah } \\
\text { (Periode 5) }\end{array}$ & $\begin{array}{c}\text { INF } \\
85.28834 \%\end{array}$ & $\begin{array}{c}\mathrm{EX} \\
6.700843 \%\end{array}$ \\
\hline $\begin{array}{l}\text { Jangka Panjang } \\
\text { (Periode 14) }\end{array}$ & $\begin{array}{c}\text { INF } \\
77.29736 \%\end{array}$ & $\begin{array}{c}\text { INV } \\
8.936346 \%\end{array}$ \\
\hline
\end{tabular}

\section{PEMBAHASAN}

Berdasarkan diketahui bahwa kebijakan untuk mengendalikan produk domestik bruto dalam jangka pendek ternyata dari produk domestik bruto itu sendiri kemudian dari suku bunga kredit. Dalam jangka menengah dan panjang rekomendasi kebijakan yang paling baik untuk mengendalikan produk domestik bruto selain produk domestik bruto itu sendiri adalah jumlah uang beredar. Besarnya jumlah uang beredar akan meningkatkan kemampuan masyarakat untuk melakukan permintaan terhadap suatu barang, kemudian naiknya permintaan akan mendorong naiknya produksi sehingga produk domestik bruto juga akan meningkat.

\section{Tabel 1}

Rekomendasi Kebijakan Untuk INF

EKSPOR $=0.63343818498 *$ EKSPOR $(-1)-0.141704921233 *$ INFLASI $(-1)-$ $0.0453281937705 * \operatorname{INVESTASI}(-1)+0.00179441393602 * \mathrm{PDB}(-1)-$ $0.004449478170405 *$ KURS $(-1)+16.1240517729$

$$
\begin{aligned}
\text { INFLASI }= & 0.0483306384202 * \operatorname{EKSPOR}(-1)+0.617352959875 * \operatorname{INFLASI}(-1)+ \\
& 0.000459504326365 * \operatorname{INVESTASI}(-1)-0.000564406652125 * \operatorname{PDB}(-1)+ \\
& 0.0007443809949805 * \operatorname{KURS}(-1)+31.6277396822
\end{aligned}
$$

\footnotetext{
INVESTASI $=27.2807696113 *$ EKSPOR $(-1)+65.8760541173 * \operatorname{INFLASI}(-1)+$ $0.542821080727 * \operatorname{INVESTASI}(-1)-0.18802548952 * \mathrm{PDB}(-1)+$ $0.680474521866 *$ KURS(-1) - 3848.81072256
} 

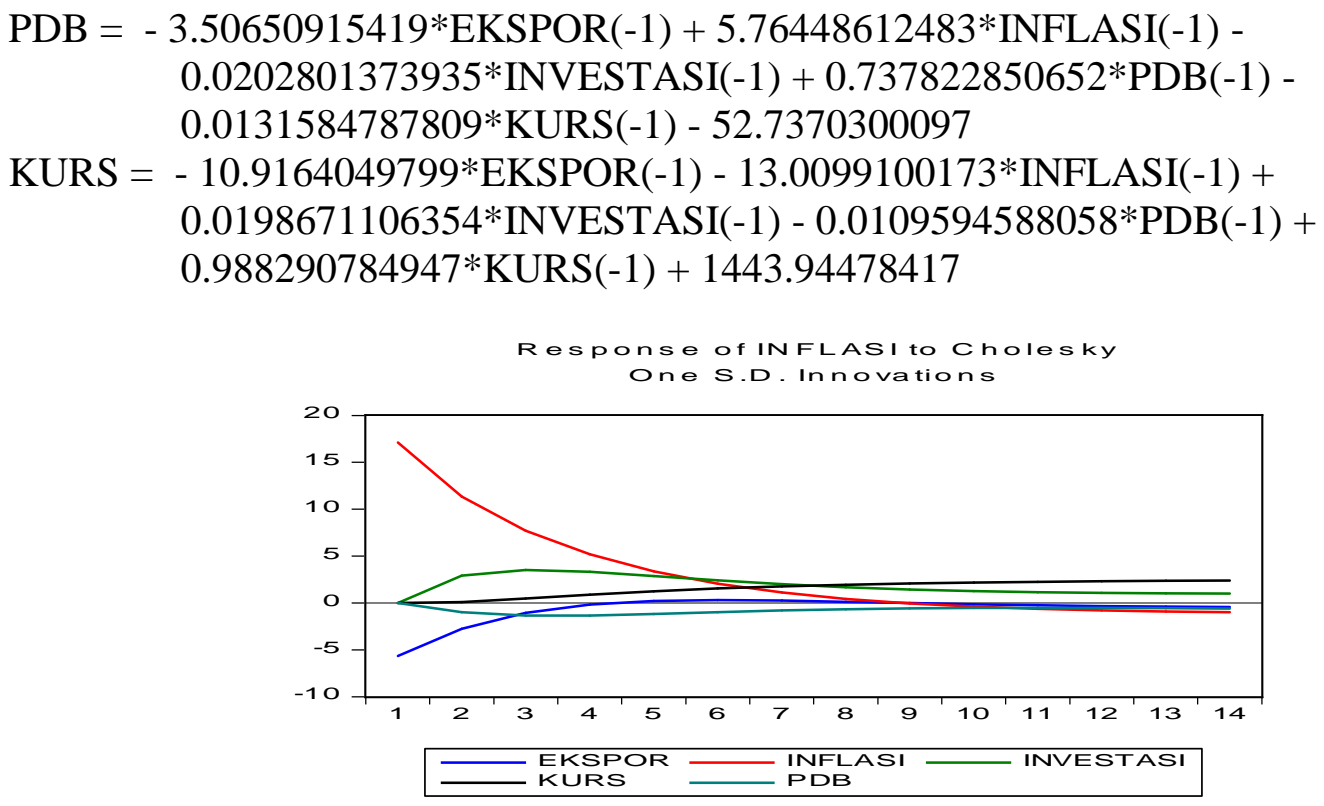

\section{Gambar 5}

Response of INflasi to Cholesky One S.D. Innovations

Hasil persamaan untuk ekspor negera emerging market diketahui ekspor tahun sebelumnya sangat mempengaruhi ekspor tahun sekarang, kemudian inflasi juga mempengaruhi signifikan. Perkembangan ekonomi yang diwakili oleh inflasi dipengaruhi oleh inflasi tahun sebelumnya dan ekspor. Investasi sangat dipengaruhi oleh inflasi dan ekspor. Untuk produk domestik bruto dipengaruhi oleh inflasi dan ekspor dan untuk kurs dipengaruhi oleh inflasi dan ekspor. Hasil tersebut menunjukkan kebijakan moneter negara-negara emerging market sangat dipengaruhi oleh inflasi dan ekspor.

\section{KESIMPULAN}

1. Hasil Analisis Vector Autoregression dengan menggunakan dasar lag 1 menunjukkan bahwa adanya kontribusi dari masing-masing variabel terhadap variabel itu sendiri dan variabel lainnya. Hasil analisa Vector Autoregression juga menunjukkan bahwa variabel masa lalu $\left(\mathrm{t}_{-1}\right)$ berkontribusi terhadap variabel sekarang baik terhadap variabel itu sendiri dan variabel lain. Dari hasil estimasi ternyata terjadi hubungan timbal balik antara variabel yang satu dengan variabel yang lainnya atau dengan kata lain semua variabel yaitu variabel kebijakan fiskal (TAX dan GOV), variabel kebijakan moneter (SBK dan JUB) dan variabel stabilitas ekonomi makro (PDB, INV, KURS, INF) saling berkontribusi.

2. Hasil Analiisis Impulse Response Function menunjukkan adanya respons variabel lain terhadap perubahan satu variabel dalam jangka pendek, menengah dan panjang, dan diketahui bahwa stabilitas respon dari seluruh variabel terbentuk pada periode 20 atau jangka menengah dan jangka panjang. Respon variabel lain terhadap perubahan satu variabel menunjukan variasi yang berbeda baik dari respon positif ke negatif atau sebaliknya, dan ada variabel yang responnya tetap positif atau tetap negatif dari jangka pendek sampai jangka panjang. 
3. Hasil Analisis Variance Decomposition menunjukan adanya variabel yang memiliki kontribusi terbesar terhadap variabel itu sendiri baik dalam jangka pendek, menengah maupun jangka panjang seperti TAX, GOV, SBK, PDB, INV, KURS. Sedangkan variabel lain yang memiliki pengaruh terbesar terhadap variabel itu sendiri baik dalam jangka pendek, menengah maupun jangka panjang adalah JUB dipengaruhi terbesar oleh PDB, dan INF yang dipengaruhi terbesar oleh SBK.

\section{DAFTAR PUSTAKA}

Agustina, Ira, 2016. Analisis Mekanisme Transmisi Kebijakan Moneter Saluran Keredit Terhadap Pertumbuhan Ekonomi Indonesia. Tesis. Universitas Jambi.

Alfian, Muhammad, 2011, Efektifitas Mekanisme Transmisi Kebijakan Moneter Pada Jalur Suku Bunga. Jurnal Media Ekonomi Vol. 19, No. 2, Agustus 2011.

Ariefianto, M,D. (2012)." Ekonometrika esensi dan aplikasi dengan menggunakan Eviews, Erlangga, Jakarta.

Aswani, J. 2015. Analyzing the Impact of Global Financial Crisis on the Interconnectedness of Asian Stock Markets using Network Science. Indira Gandhi Instite of Development Reseach, Mumbai. WP-2015-020

Held, David dan Anthony McGrew. (2012). “A Global Economy?”, dalam Globalization/Anti-Globalization, Oxford: Blackwell Publishing Ltd., pp. 38-57

Goeltom, Miranda S. (2008). Mekanisme transmisi kebijakan moneter di Indonesia (Krisis 1997/1998 -1999/2000 dan Setelah krisis 2000:01 - 2005:03) . BIS Papers No 35. Bank Of International Settlement

Gujarati, D. N. (2011). Ekonomtrika Dasar. (Edisi Alih Bahasa Terjemahan). Jakarta: Erlangga

Hardianto, Y, 2012. Teori Portofolio Dan Analisis Investasi, Cetakan Keenam. Yogyakarta: Universitas Gadjah Mada.

Manurung, Jonni, J. Manurung, Adler H., Saragih, F D, 2009. Ekonometrika. Cetakan Pertama, Elex Media Computindo, Jakarta.

Mahendra, I Gede Yoga Kesumajaya, I Wayan Wita (2015). Analisis Pengaruh Investasi, Inflasi, Kurs Dollar Amerika Serikat Dan Suku Bunga Kredit Terhadap Ekspor Indonesia. E-Jurnal Ekonomi Pembangunan Universitas Udayana Vol. 4, No. 5, Mei 2015 (pp. 348 - 607).

Martha Simbolon, 2012, Analisis Perbandingan Peranana Jalur Suku Bunga dan Jalur Nilai Tukar Dalam Mekanisme Transmisi Kebiijakan Moneter Di Indonesia. USU.

Meric, I: Kim, J.H: Gong, L \& Meric, G. (2012). Co-movement of and Linkages between Asian Stock Markets. Business and Economics Research Journal, Vol. 3, No.1, ISSN: 1309-2448.

Pohan, Aulia, 2008. Kerangka Kebijakan Moneter \& Implementasinya Di Indonesia . PT. Rajagrafindo Persada, Jakarta.

Rusiadi,et-al, 2014. Metode Penelitian Untuk Manajemen, Akuntansi dan Ekonomi Pembangunan, Konsep, Kasus dan Aplikasi SPSS, Eviews, Amos dan Lisrel. Cetakan kedua. USU press, Medan.

Saida Hasibuan, 2016. Mekanisme Transmisi Kebijakan Moneter Melalui suku bunga BI 7- Day Repo Rate (BI7DRR) Sebagai Sasaran Operasional Kebijakan Moneter Dan Variabel Makroekonomi Indonesia. 
Subagyo, Priyadi Asmanto. 2007. Unair. Analisis Pengaruh Kebijakan Moneter Dan Kebijakan Fiskal Regional Terhadap Stabilitas Harga Dan Pertumbuhan Ekonomi Regional Di Jawa Timur.

Santoso, Teguh, 2009. Dampak Kebijakan Ffiskal dan Moneter dalam Perekonomian Indonesia. (periode 1997.4 - 1998.4 dalam kwartal).

Sunyoto, Danang. 2011, Metode Penelitian Ekonomi. Cetakan Pertama. CAPS : Yogyakarta.

Yeniwati, dan Riani, 2014. Jalur Kredit Perbankan Dalam Mekanisme Transmisi Kebijakan Moneter di Indonesia.

Yulia Indrawati, 2007, Interaksi Kebijakan fiskal dan Moneter di indonesia: Pendekatan Vector Autoregression. Tesis. Undip. 